\title{
ANALISIS POTENSI PENERIMAAN RETRIBUSI PASAR SEBAGAI SALAH SATU SUMBER PENDAPATAN ASLI DAERAH KABUPATEN HULU SUNGAI UTARA
}

\author{
Oleh: \\ Ahsani Fauzan \\ Jurusan Ilmu Ekonomi Dan Studi Pembangunan, Fakultas Ekonomi, \\ Universitas Muhammadiyah Malang \\ ahsanifauzan@gmail.com
}

\begin{abstract}
Market retribution market is one of sources of local revenue in Hulu Sungai Utara. The purpose of this study is to measure the potential revenue, market in Hulu Sungai Utara, which results will be used as a basic reference potential measure the effectiveness of revenue, market, in order to assess the results of the performance of market fee collection. This type of research is research diskiptif, while the data analysis method in use is the qualitative method, ie with a portrait, explain, and interpret the date obtained and analyzed to obtain conclusions.

Contribution revenue, market on revenue is relatively small with only contributes a percentage rate 5\%, from the year 2009 until the year 2012 revenue, always increasing but retribution market acceptance of is not comparable to the total revenues of local revenue Hulu Sungai Utara. Development of retribution market has increased every year, but in 2012 the increase in 2011 the difference is slight. Revenue, market the Department of Revenue in Hulu Sungai Utara against the target revenue, the market has not reached that yet effective, this is due to the realization of revenue, the market does not meet the expected targets, while potential market acceptance levy of 11 kinds of receipts in Hulu Sungai Utara Rp 1.947.378.000. The number is the whole of the potential is there, but can be developed by adding new facilities.
\end{abstract}

Keywords: Market Retribution, Regional Potential, Local Revenue.

\footnotetext{
Abstrak

Pasar retribusi merupakan salah satu sumber pendapatan daerah di Hulu Sungai Utara. Tujuan dari penelitian ini adalah untuk mengukur potensi pendatan pasar di Hulu Sungai Utara, yang hasilnya akan digunakan sebagai potensial referensi ukuran dasar efektivitas pendapatan, pasar untuk menilai hasil kinerja pasar. Jenis penelitian ini adalah penelitian diskriptif, sedangkan metode analisis data yang digunakan adalah metode kualitatif, yaitu dengan potret, menjelaskan dan menafsirkan hasil yang diperoleh dan dianalisis untuk memperoleh kesimpulan. Penerimaan iuran pendapatan pasar relatif kecil dengan hanya memberikan kontribusi tingkat persentase 5\%, dari tahun 2009 sampai dengan pendapatan
} 
tahun 2012, selalu meningkat namun penerimaan retribusi pasar dari tidak sebanding dengan pendapatan total pendapatan daerah Hulu Sungai Utara. Pengembangan pasar retribusi telah meningkat setiap tahun, tetapi pada tahun 2012 meningkat pada tahun 2011 perbedaannya adalah sedikit. Pendapatan, pasar Departemen Pendapatan di Hulu Sungai Utara terhadap target pendapatan, pasar belum mencapai itu belum efektif, hal ini disebabkan realisasi pendapatan, pasar tidak memenuhi target yang diharapkan, sementara potensi penerimaan pasar retribusi dari 11 jenis penerimaan di Hulu Sungai Utara Rp 1.947.378.000. Jumlah ini seluruh potensi yang ada, namun dapat dikembangkan dengan menambah fasilitas baru.

Kata kunci: Retribusi pasar, potensial regional, Pendapatan Asli Daerah

\section{PENDAHULUAN}

Di Indonesia setiap daerah menjadikan retribusi sebagai salah satu sumber pendapatan daerah.

Menurut Mahmudi (2010:73) retribusi daerah mempunyai jenis yang lebih beragam, namun tidak semua retribusi tersebut potensial dalam arti memberikan kontribusi terhadap pendapatan asli daerah secara signifikan. Perbedaan utamanya adalah pungutan retribusi memiliki keterkaitan langsung dengan pelayanan yang diberikan atau memperoleh imbalan berupa jasa yang dapat dinikmati secara langsung.

Sumber penerimaan daerah berupa retribusi salah satunya adalah dari sektor penerimaan retribusi pasar. Retribusi itu berupa pelayanan langsung dari pemerintah daerah untuk menyediakan tempat pasar yang layak dan strategis. Pemerintah daerah akan melakukan pemungutan retribusi kepada setiap pengguna sarana pasar. Sedangkan dari pihak masyarakat akan menerima timbal balik jasa yang diberikan pemerintah daerah.

Kalimantan Selatan. Hulu Sungai Utara: Dinas Pendapatan, Bidang Pendataan, 2013. Jumlah pasar yang terdapat di Kabupaten Hulu Sungai Utaara yang terdiri dari 10 kecamatan adalah sebanyak 9 jenis yaitu, Pasar Amuntai, Pasar Alabio, Pasar Itik Alabio, Pasar Itik Baru, Pasar Danau Panggang, Pasar Babirik, Kantin, Pertokoan Rakyat Muara Tapus, dan Plaza Amuntai dari keseluruhan potensi yang ada potensi retribusi pasar meliputi tarif kios/pertokoan.

Menurut Setiawan dan Suprapti (2002:134) menentukan 
target penerimaan retribusi pasar pemerintah harus mengetahui berapa besar potensi retribusi pasar, agar potensi tersebut dapat dioptimalkan untuk dapat meningkatkan retribusi pasar. Potensi retribusi pasar tersebut akan menjadi acuan bagi pemerintah untuk menentukan target penerimaan retribusi pasar. Target tersebut nantinya akan dibandingkan dengan realisasi penerimaan retribusi pasar untuk mengukur tingkat efektivitas penerimaan retribusi pasar.

Efektivitas penerimaan retribusi pasar ditujukan untuk meningkatkan pendapatan asli daerah. Faktor-faktor yang mempengaruhi penerimaan retribusi pasar yaitu subjek dan objek pasar, tarif retribusi, sistem pemungutan retribusi, kebijakan pemerintah, dan aparat pelaksanaan retribusi pasar. Peran lebih dari pemerintah dalam meningkatkan retribusi pasar harus ditingkatkan agar kinerja pemungutan retribusi berjalan efektif.

Upaya yang harus dilakukan pemerintah yaitu mengawasi kegiatan pemungutan retribusi pasar agar tidak ada kecurangan oleh pihak pemungut sehingga akan menurunkan penerimaan retribusi pasar. Selain itu kesadaran dari pihak pedagang dipasar juga harus diperhatikan dalam membayar retribusi pasar agar peningkatan retribusi pasar sesuai dengan apa yang diharapkan.

Peningkatan penerimaan retribusi pasar harus didukung melalui upaya perbaikan struktur dan sistem yang baik guna peningkatan efektivitas pemungutan. Jika realisasi penerimaan retribusi pasar semakin besar maka semakin mendekati target yang ditetapkan, maka hal tersebut menunjukkan efektivitasnya semakin besar. Jika efektivitas dapat tercapai diharapkan dapat memberikan kontribusi untuk peningkaan pendapatan asli daerah.

Kontribusi retribusi pasar akan meningkatan pendapatan asli daerah jika dikelola dengan lebih efektif. Dalam pemungutan retribusi pasar agar mudah dalam pemungutanya pemerintah harus mengatur dan membuat denah toko atau kios yang ada dipasar sesuai dengan jenis penjualan agar lebih tertib. Semakin tinggi pendapatan asli daerah yang berasal dari pemungutan retribusi pasar maka akan lebih meningkatkan 
pendapatan asli daerah. Selain itu, kontribusi retribusi pasar hasilnya nyata terhadap pendapatan asli daerah..

\section{METODE PENELITIAN}

Jenis penelitian yang digunakan adalah penelitian deskriptif dan kuantitatif, yaitu memberikan gambaran atau penjelasan mengenai kebijakan retribusi pasar dengan mengkaji secara terperinci latar belakang pelaksanaan retribusi pasar serta efektivitasnya yang berhubungan dengan pencapaian target yang ditetapkan (Sanusi, 2013:13).

Metode analisis data yang dipakai adalah metode analisis kualitatif, yaitu dengan menggambarkan, menerangkan, serta menginterpretasikan data yang diperoleh yang kemudian dianalisis untuk mendapatkan suatu kesimpulan.

1. Kontribusi Penerimaan Retribusi Pasar Terhadap Pendapatan Asli Daerah. (Bappenas, 2003)

$\mathrm{KPR}=\frac{\mathrm{PR}_{\text {th }-\mathrm{n}}}{\mathrm{PAD}_{\text {th }-\mathrm{n}}} \times 100 \%$

Dimana :

$$
\begin{aligned}
\text { KPR = } & \text { Kontribusi retribusi } \\
& \text { pasar terhadap }
\end{aligned}
$$

$$
\begin{aligned}
& \text { pendapatan asli } \\
& \text { daerah } \\
& \mathrm{PR}_{\text {th-n }}=\text { Penerimaan } \\
& \text { retribusi pasar } \\
& \mathrm{PAD}_{\text {th-n }}=\text { Penerimaan } \\
& \text { pandapatan asli } \\
& \text { daerah }
\end{aligned}
$$

2. Menganalisis Perkembangan Dari Penerimaan Pemungutan Retribusi Pasar, (Bappenas, 2003)

$$
\begin{aligned}
& \mathrm{P}_{\mathrm{PR}} \\
& =\frac{\mathrm{PR}_{\mathrm{th}-\mathrm{n}}-\mathrm{PR}_{\mathrm{th}-\mathrm{n}-1}}{\mathrm{PR}_{\mathrm{th}-\mathrm{n}-1}} \times 100 \%
\end{aligned}
$$

Dimana :

$$
\begin{array}{rlr}
\mathrm{P}_{\mathrm{PR}}= & \text { Perkembangan retribusi } \\
& \text { pasar } & \\
\mathrm{PR}_{\mathrm{th}-\mathrm{n}}= & \text { Penerimaan } & \text { retribusi } \\
& \text { pasar } & \\
\mathrm{PR}_{\text {th-n-1 }}= & \text { Penerimaan } & \text { retribusi } \\
& \text { pasar } & \text { tahun } \\
& \text { sebelumnya } &
\end{array}
$$

3. Menganalisis Efektivitas Pelaksanan Pemungutan Retribusi Pasar. Devas CN (1989) $\mathrm{Y}_{\mathrm{AP}}=\frac{\mathrm{R}_{\mathrm{PAD}}}{\mathrm{P}_{\mathrm{PAP}}} \times 100 \%$ Dimana :

$$
\begin{aligned}
\mathrm{Y}_{\mathrm{AP}}= & \text { Efektivitas } \\
\mathrm{R}_{\mathrm{PAD}}= & \text { Realisasi penerimaan } \\
& \text { retribusi pasar } \\
\mathrm{P}_{\mathrm{PAP}}= & \text { Anggaran penerimaan } \\
& \text { retribusi pasar }
\end{aligned}
$$


4. Mengukur Potensi Penerimaan Retribusi Pasar. Mahyadi (2010:73)

$$
\mathrm{P} \quad=(\mathrm{J} \times \mathrm{TRP}) \times 12 \text { bulan }
$$

Dimana :

$$
\begin{aligned}
\mathrm{P}= & \text { Potensi } \\
\mathrm{J}= & \text { Jumlah kios/pertokoan } \\
\mathrm{TRP}= & \text { Tarif retribusi pasar per } \\
& \text { bulan }
\end{aligned}
$$

\section{PEMBAHASAN}

Kontribusi retribusi pasar terhadap pendapatan asli daerah relatif kecil. Karena penerimaan retribusi pasar tidak sebanding dengan total penerimaan asli daerah. Kontribusi penerimaan retribusi pasar terhadap pendapatan asli daerah dari tahun 2009 sampai tahun 2012 selalu mengalami peningkatan. Hal ini disebabkan karena pertumbuhan pada peningkatan pendapatan asli daerah sebanding dengan peningkatan penerimaan pemungutan retribusi pasar. Tetapi melihat potensi retribusi pasar pendapatan dari retribusi pasar harus di pertahankan agar tetap memberikan kontribusi kepada pandapatan asli daerah.

Perkembangan penerimaan retribusi pasar mengalami peningkatan tahun dari 2009 sampai dengan tahun 2012. Tetapi penerimaan retribusi pasar belum sesuai dengan target yang diharapkan.

Perkembangan penerimaan retribusi pasar tahun 2011 mengalami perkembangan yang tinggi, yaitu sebesar 24,79\%, karena tahun 2011 dinas pendapatan melakukan upaya peningkatan dalam hal pemungutan retribusi pasar melalui sosialisasi kepada pedagang. Efektivitas penerimaan retribusi pasar Kabupaten Hulu Sungai Utara terhadap target retribusi pasar tidak efektif. dilihat dari realisasi penerimaan retribusi pasar belum memenuhi target yang ditentukan. Sedangkan dalam menentukan tingkat efektivitas penerimaan retribusi pasar seharusnya didasarkan pada potensi retribusi pasar yang ada. Untuk itu perlu dilakukan perhitungan efektivitas berdasarkan potensi yang ada dan seharusnya lebih realistis.

Potensi penerimaan retribusi pasar di Kabupaten Hulu Sungai Utara sebesar Rp 1.947.378.000,00. Jumlah tersebut adalah keseluruhan dari potensi retribusi pasar di 
Kabupaten Hulu Sungai Utara.

Potensi tersebut masih bisa dikembangkan dengan menambah fasilitas di pasar. Selama tahun 2009 sampai dengan tahun 2012 potensi pasar di Kabupaten Hulu Sungai Utara tidak mengalami pertumbuhan, dengan perbaikan sistem penagihan dan permahaman pemerintah semakin luas kepada masyarakat maka potensi akan jauh lebih besar.

\section{PENUTUP}

1. Kontribusi penerimaan retribusi pasar terhadap Pendapatan Asli Daerah dari tahun 2011 presentase $5,55 \%$ dan mengalami penurunan pada tahun 2012 Presentase $5,19 \%$ hal ini di sebabkan kenaikan penerimaan retribusi dari tahun sebelumnya sedikit, di bandingkan dengan kenaikan PAD yang jauh lebih besar sehingga terjadi penurunan presentasedengan kontribusi relatif kecil, karena peningkatan pendapatan daerah tidak sebanding dengan peningkatan penerimaan retribusi pasar.

2. Perkembangan retribusi pasar dari tahun 2009 sampai dengan tahun 2011 mengalami peningkatan dengan presentase $24,79 \%$ namun mengalami penurunan presentase 5,91\% pada tahun 2012 karena penerimaan retribusi pasar dari tahun 2011 selisihnya kecil.

3. Efektivitas penerimaan retribusi pasar pada Dinas Pendapatan Daerah di Kabupaten Hulu Sungai Utara terhadap target penerimaan retribusi pasarbelum efektif. Hal ini bisa dilihat darirealisasi penerimaan retribusi pasar belum memenuhi target yang ditentukan. Sedangkan efektivitas target retribusi pasar terhadap potensi penerimaan retribusi pasar mengalami kenaikan dan penurunan, penurunan terjadi pada tahun 2011 selisih Rp 308.460.049 hasilnya belum efektif dalam mencapai seluruh potensi retribusi pasar.

4. Potensi penerimaan retribusi pasar di Kabupaten Hulu Sungai Utara yaitu Rp 1.947.378.000 jumlah tersebut adalah keseluruhan potensi yang ada di daerah Kabupaten Hulu Sungai Utara. Potensi retribusi pasar meliputi tarif kios/pertokoan di pasar. 
Saran dari peneliti terkait penelitian kepada objek penelitian adalah sebagai berikut:

1. Dalam penetapan target retribusi pasar, pemerintah daerah harus mengkaji ulang potensi yang ada dan sesuai dengan kondisi terbaru yang ada di pasar. Sehingga dapat digunakan sebagai dasar penilaian efektivitas yang lebih akurat.

2. Melakukan pembaharuan data para wajib retribusi tetap yang sesuai dengan kondisi pasar terbaru, sehingga memudahkan dalam aktivitas pemungutan retribusi pasar.

\section{DAFTAR PUSTAKA}

Amrijaya (2007). Analisis sistem pengendalian intern pemungutan retribusi pajak daerah untuk mengetahui tingkat efektifitas pendapatan daerah pada Pemerintah Daerah Kota Kediri. Universitas Muhammadiyah Malang.

Bappenas. 2003. Peta kemampuan provinsi dalam era ttonomi daerah. Tinjauan atas kinerja pendapatan asli daerah (PAD), dan upaya yang dilakukan daerah: Derektorat Pembangunan Otonomi Daerah.
Devas. C.N. Keuangan Pemerintah Daerah di Indonesia, Jakarta, UII Press, 1989.

Kamaroellah, R Agoes (2006). Analisis kontribusi penerimaan retribusi pasar terhadap pendapatan asli daerah (PAD) pada Dinas Pendapatan Daerah Kabupaten Pamekasan. Universitas Islam Zmadura (UIM) Pamekasan.

Kesit, Bambang Prakosa (2003). Pajak dan Retribusi daerah, Yogyakarta: UII Press.

Lissiana, Meria (2006). Analisis pemungutan retribusi pasar guna meningkatkan efektifitas pendapatan daerah Kabupaten Pamekasan (studi kasus pada Dinas Pendapatan Asli Daerah Kabupaten Pamekasan). Universitas Muhammadiyah Malang.

Mahmudi (2010). Manajemen Keuangan Daerah, Jakarta: Erlangga.

Mustaqiem, 2008, Pajak Daerah Dalam Transisi Otonomi Daerah, FH UII Press, Yogyakarta.

Saleh, Aziz (2008). Sistem pengendalian intern terhadap pungutan retribusi pasar dalam rangka peningkatan pendapatan asli daerah (Studi kasus pada dinas pendapatan daerah kota Batu). Universitas Muhammadiyah Malang. 
Sanusi, Anwar (2013). Metodologi penelitian bisnis, Jakarta: Salemba Empat.

Setiawan, Setu dan Eny Suprapti (2002). Perpajakan, Malang: UMM Press.

Setyaningsih, Lilik (2005), Analisis sistem pengendalian intern pemungutan retribusi pasar untuk mencapai efektifitas penerimaan pendapatan dinas pasar kabupaten Malang.Universitas

Muhammadiyah Malang.

Suandi, Erly (2011). Hukum pajak, Yogyakarta: Salemba Empat.

Sunarto (2005). Pajak dan Retribusi Daerah, Yogyakarta: AMUS Yogyakarta dan Citra Pustaka Yogyakarta.

Sutrisno, Mohammad (2014). Analisis potensi retribusi pasar sebagai salah satu sumber pendapatan asli daerah Kabupaten Kediri. Universitas Muhammadiyah Malang.

Wahyudi, Dwi Sri (2006). Analisis retribusi pasar terhadap peningkatan pendapatan asli daerah (PAD) sebelum dan sesudah otonomi daerah di kabupaten Blitar. Universitas Muhammadiyah Malang. 